\title{
The Ability of Root Canal Irrigant With Ethanol Extract of Lerak Fruit (Sapindus Rarak Dc) in Removing Root Canal Smear Layer (A Sem Study)
}

\author{
Nevi Yanti, Dennis², \\ Department Of Conservative Dentistry Faculty Of Dentistry, University Of Sumatera Utara \\ Jl. Alumni No. 2 Kampus USU Medan-20155
}

\begin{abstract}
Abstrak: Application of root canal irrigant is one of the factors that affect the success of endodontic treatment. Unfortunately, there is no single irrigant which qualify as an ideal irrigant. Lerak fruit can be used as an alternative irrigant for root canal irrigation due to almost qualify as an irrigant. The aim of the study was to evaluate the ability of various root canal irrigants in removing root canal smear layer. Samples of 50 human extracted mandibular premolars were done crown separation at the CEJ. All samples were divided into 5 groups and prepared endodontically by ProTaper Universal Ni-Ti Rotary Instruments up to size F3 and each group was irrigated with corresponding solution $3 \mathrm{ml}$ in between each file for 36 seconds and $5 \mathrm{ml}$ as final irrigant for 60 seconds as following, Group I: 25\% ethanol extract of the fruit lerak, Group II: the combination of 25\% ethanol extract of the lerak fruit and 2.5\% $\mathrm{NaOCl}$, Group III: irrigated with 2,5\% $\mathrm{NaOCl}$ and followed by final irrigant with EDTA 17\%, IV: NaOCl 2.5\% and followed by final irrigant with maleic acid $7 \%$ and V: saline. Each sample was rinsed with $2 \mathrm{ml}$ saline and dried with paper points. Samples was then split into two halves from buccolingually direction and tested sent for SEM photograph at 1000x magnification on the apical third. Measuring the level of cleanliness of root canal from smear layer was determined by Torabinejad scoring (2003). Analyze data were tested with Kappa statistics, Kruskal-Wallis and Mann-Whitney. The results showed that there were differences of ability the various irrigants in removing smear layer on apical third of root canal $(p<0.05)$. It can be concluded that $25 \%$ ethanol extract of the lerak fruit had ability to remove smear layer on the apical third of root canal and more effective than 2.5\% $\mathrm{NaOCl}$ with $17 \%$ EDTA and $\mathrm{NaOCl} 2.5 \%$ with $7 \%$ maleic acid.
\end{abstract}

Keywords: lerak, root canal irrigant, smear layer

\section{I.Introduction}

The goal of endodontic therapy is the removal of all vital or necrotic tissue, microorganisms from the root canal system and prevent recurrent infection. ${ }^{1,2}$ This may be achieved through chemomechanical preparation of root canal. ${ }^{1,2}$ Chemomechanical preparation of the root canal includes both irrigation and mechanical instrumentation. $^{2}$ Root canal instrumentation roles on shaping and the enlarge root canal system to facilitate adequate irrigation and obturation of root canal. Root canal instrumentation enables the removal of the pulpal tissues, both inflamed and necrotic from root canal. However, mechanical instrumentation can cause some changes on the inner dentin walls of the root canal occur, yielding a micro layer named as "the smear layer. ${ }^{4}$ Smear layer can be a substrate for bacteria that allowing bacteria may survive and multiply and proliferate into the dentinal tubules ${ }^{5,6}$ Smear layer may interfere the adaptation and penetration of sealer into dentinal tubules and can lead to microleakage on apical third root canal. ${ }^{5,6}$

Shahravan et al. (2007) concluded that removal of smear layer reduce apical leakage. ${ }^{6,7}$ Therefore, the use of irrigant that can remove smear layer is really needed for cleaning and disinfecting root canals compeletely. An ideal irrigant should remove both organic and inorganic smear layer without harmful erosive effect on dentine. Various irrigants have been used to remove smear layer. ${ }^{7}$

Sodium hypochlorite $(\mathrm{NaOCl})$ in a concentration of $0.5 \%$ to $5.25 \%$ is an irrigant solution widely used in root canal irrigation because of its bactericidal properties and ability to dissolve organic tissue. ${ }^{1,7} \mathrm{NaOCl}$ with high concentrations are toxic and cannot remove inorganic smear layer Thus, the use of $\mathrm{NaOCl}$ must be combined with the other irrigant. ${ }^{1,9}$ Unfortunately, no irrigating solution is capable acting silmutaneously on the organic and inorganic elements of the smear layer. Thus, the use of use of $\mathrm{NaOCl}$ is often used to be combinated with chelating agent. ${ }^{7}$

EDTA in a concentration of $15 \%$ to $17 \%$ is one of the chelating agent that effectively removes inorganic smear layer and relatively non toxic. ${ }^{1,3}$ However, EDTA has little antibacterial effect and inability to dissolve organic tissue so it cannot dissolve organic smear layer. In addition, EDTA resulted in the erosion effects on dentin. ${ }^{8}$ Silveira et al. (2013) reported that $2.5 \% \mathrm{NaOCl}$ and $17 \%$ EDTA determined that effective in removing smear layer on the coronal third and middle third of the root canal, but ineffective on apical third root canal. ${ }^{8}$ The use of EDTA alone or prior to resulted in maximum decrease in dentin microhardness. ${ }^{7}$ 
Maleic acid can be used as an alternative solution for EDTA irrigation because of its ability to remove inorganic smear layer. Maleic acid is able to eliminate the smear layer more effectively and efficiently than EDTA on the apical third root canal. ${ }^{10,11}$ Ballal et al. (2009) reported that $7 \%$ maleic acid has ability to remove the smear layer on root canal dentin..$^{10,11}$ However, maleic acid in concentrations of $10 \%$ or more can damage and demineralize intertubular dentin. ${ }^{10}$

Due to the weakness of irrigation materials that is often used, using natural materials as an alternative of root canal irrigation materials that can be expected to be better and more biocompatible so it can be used clinically. ${ }^{12}$

Lerak fruit (Sapindus rarak DC) is one of the natural material that can be developed as an root canal irrigant. Efficacy of pharmacological lerak fruit among others, as an antifungal, bactericidal and antiinflammatory. ${ }^{13}$ Active components of lerak fruit consist of saponin, alkaloid, polyphenol, and flavanoid. ${ }^{14,15}$ The main component of lerak fruit is a saponin which is a surface active compound as surfactant (surface tension decreasing) and detergent that can be expected to remove smear layer on root canal system. ${ }^{14}$

Ethanol extract of lerak fruit can be used as an alternative to root canal irrigant for nearly has all requirements as a root canal irrigant. The surface tension of 5-25\% ethanol extract of lerak fruit are lower than the $2.5 \% \mathrm{NaOCl}^{16}$, antibacterial effects of ethanol extract of lerak fruit ranged from $0.01 \%$ to $25 \%$; against Streptococcus mutans in a concentration of $0.01 \%^{17}$, Fusobacterium nucleatum in a concentration of $0.25 \%{ }^{18}$, Porphyromonas gingivalis ${ }^{19}$ and Enterococcus bacteria faecalis ${ }^{20}$ in concentration of $25 \%$ and its ability in dissolving pulp tissue ranged from $6.25 \%$ to $25 \%$ and more effective compared $\mathrm{NaOCl} 2.5 \%$, Therefore, the concentration of ethanol extract of lerak fruit used are $25 \%$ more likely to have influence as to provide the requirements as root canal irrigant.

The aim of this in vitro study were to evaluate the efficacy of $25 \%$ ethanol extract of lerak fruit in removing smear layer of root canal.

\section{Extraction of lerak fruit}

\section{II.Material and Method}

Lerak fruit $1 \mathrm{~kg}$ was washed with running water and then taken the seeds then weighed and gained as much as 940 grams of lerak flesh. Then cut into small pieces $\pm 3 \mathrm{~mm}$ and dried in a drying cabinet at a temperature of \pm $40{ }^{\circ} \mathrm{C}$ for a week. Lerak fruit was already dried, mashed with a blender and diluted with ethanol to be macerated and then inserted into the percolator while adding ethanol. Results of percolate evaporated with vacuum rotavapor in order to obtain brown colored viscous lerak extract as much as 240 grams. Ethanol extract of lerak fruit put in a glass bottle and then stored in the refrigerator. Lerak extract was diluted to be in concentration $25 \%$ for use as irrigant.

\section{Sample preparation}

Fifty extracted mandibular premolars teeth for orthodontic treatment (sample criteria: single root canal, crowns and roots are complete and no caries, root in relatively straight, roots and apical foramen has been formed and no calcification of the root canal) stored in saline solution before being treated. The teeth were decoronated at cementoenamel junction using a separating disk. Working length of each sample was determined by measuring the length of the tooth and reduced $1 \mathrm{~mm}$. Then, the tooth was placed on the bais during the process of root canal preparation.

Irrigating of root canal using $5 \mathrm{ml}$ syringe with needle type two-side and size $30 \mathrm{G}$ in accordance with the respective treatment groups, namely:

- Group I:Initial irrigation with $5 \mathrm{ml} 25 \%$ ethanol extract of lerak fruit for 60 seconds, irrigation between instrument with $3 \mathrm{ml} \mathrm{25 \%}$ ethanol extract of lerak fruit for 36 seconds and final irrigation with $5 \mathrm{ml} 25 \%$ ethanol extract lerak for 60 seconds. Rinse with $2 \mathrm{ml}$ saline.

- Group II: Initial irrigation with $5 \mathrm{ml} 25 \%$ ethanol extract lerak $5 \mathrm{ml}$ for 60 seconds and $\mathrm{NaOCl} 2.5 \% 5 \mathrm{ml}$ for 60 seconds, irrigation between instrument with $3 \mathrm{ml} \mathrm{25 \%}$ ethanol extract of lerak fruit for 36 seconds and $3 \mathrm{ml}$ $\mathrm{NaOCl} 2.5 \%$ for 36 seconds and final irrigation with $5 \mathrm{ml} 2.5 \% \mathrm{NaOCl}$ for 60 seconds. Rinse with $2 \mathrm{ml}$ saline.

- Group III: Initial irrigation with $5 \mathrm{ml} 2.5 \% \mathrm{NaOCl}$ solution for 60 seconds, irrigation between instrument with 3 $\mathrm{ml} 2.5 \% \mathrm{NaOCl}$ solution for 36 seconds, final irrigation with $5 \mathrm{ml}$ 17\% EDTA for 60 seconds and rinse with 2 $\mathrm{ml}$ saline.

- Group IV: Initial irrigation with $5 \mathrm{ml} 2.5 \% \mathrm{NaOCl}$ solution for 60 seconds, irrigation between instrument with 3 $\mathrm{ml} 2.5 \% \mathrm{NaOCl}$ solution for 36 seconds, final irrigation with maleic $7 \%$ then rinse with $2 \mathrm{ml}$ saline.

- Group V: Initial irrigation with $5 \mathrm{ml}$ saline for 60 seconds, irrigation between instrument with $3 \mathrm{ml}$ saline for 36 seconds and irrigation final with $5 \mathrm{ml}$ saline for $60 \mathrm{sec}$. Rinse with $2 \mathrm{ml}$ saline.

Root canal preparation using crown-down pressureless technique using rotary NiTi ProTaper Universal instruments (Dentsply- Maillefer, Switzerland) with file S1, S2, F1, F2 and F3 at the speed of $300 \mathrm{rpm}$ and torque $2.5 \mathrm{~N} / \mathrm{cm}$. Before using the S1 file, negotiating root canal with K-file \#10 and \#15 to working length. Preparation 
with ProTaper files started with S1 and S2 until working length in brushing motion. Then, the preparation with file F1, F2 and F3 until working length in non-brushing.motion Each turn of the file was always done apical confirmation by k-file \#10. After root canal preparation is completed, the final irrigation of root canal and rinse with saline and then dried root canal with paper points.

\section{Observations on Sample}

Samples will be measured from cementoenamel junction to the apex tip. Each root was notched carefully longitudinally buccally and lingually without penetrating the canal using a separating disc. The roots were split and gently into two halves using a chisel.

Samples were examined under the Scanning Electron Microscope (SEM) - JEOL JSM-6390A. Samples were inserted into the vacuum chamber in the SEM and did magnification 10x and 1000x. 10x magnification is to determined the area of the apical third and then did 1000x magnification to observe the smear layer on apical third of root canal. To 1000x magnification, the images will be divided into nine observation area was assessed by using a scoring method through observation conducted double blind two times by different people. Measuring the level of cleanliness the root canal from smear layer provided on the observation nine area can be determined by using a score Torabinejad (2003) ${ }^{22}$, namely:

$1=$ no smear layer: no or minimal smear layer on the root canal surface; all tubules were clean and open.

$2=$ moderate smear layer: no smear layer on the root canal surface, but the dentinal tubules contained smear layer. 3 = heavy smear layer: smear layer covered the root canal surface and dentinal tubules. at 0,05 level.

After scoring, analyze data with kappa statistic, Kruskal Wallis and Mann Whitney and significant tested

\section{Results}

The results of SEM images on apical third area in all treatment groups showed that smear layer, but in a different score. SEM results in 1000x magnification and the scores given by the observer can be seen in Figure $1,2,3,4$ and 5 .

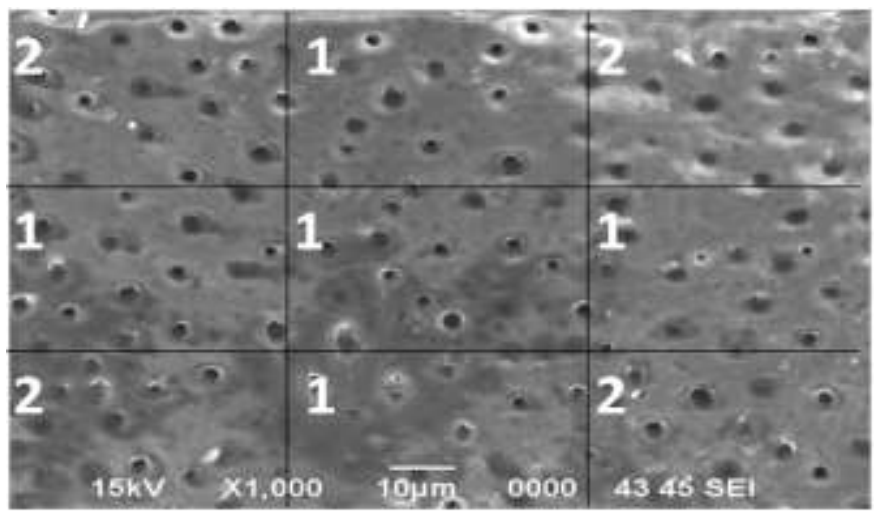

Figure 1. SEM image and scores given by observer of $25 \%$ ethanol extract of lerak fruit solution

(X 1000)

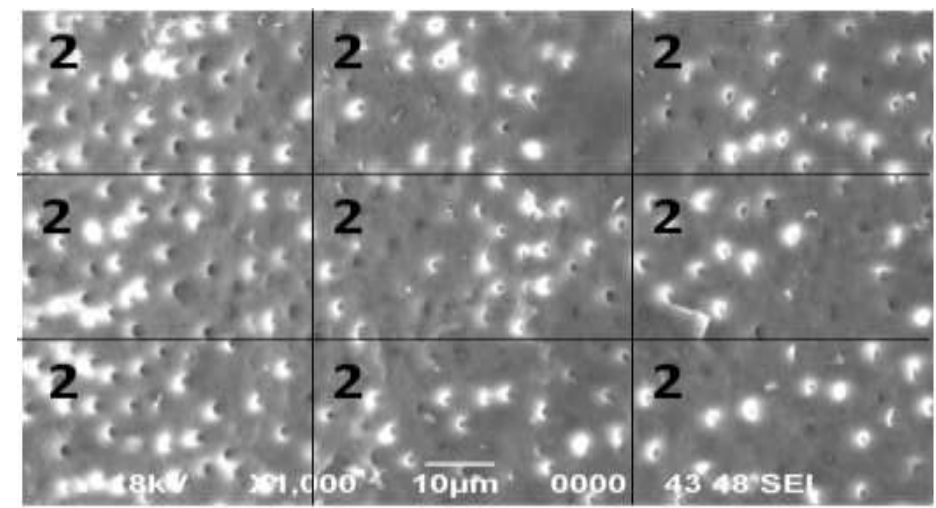

Figure 2. SEM image and scores given by observer of $25 \%$ ethanol extract of lerak fruit and $2,5 \% \mathrm{NaOCl}$ solution ( X 1000) 


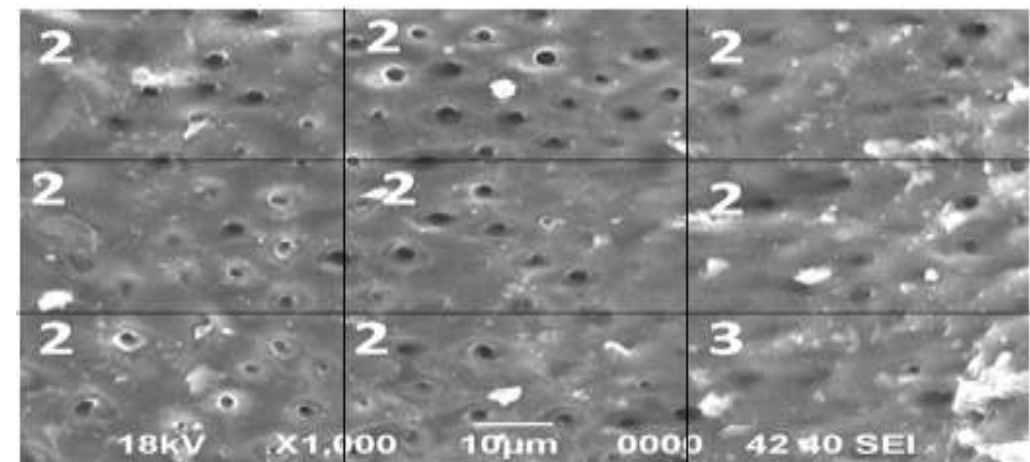

Figure 3. SEM image and scores given by observer of 2,55\% NaOCl and 17\% EDTA solution ( X 1000)

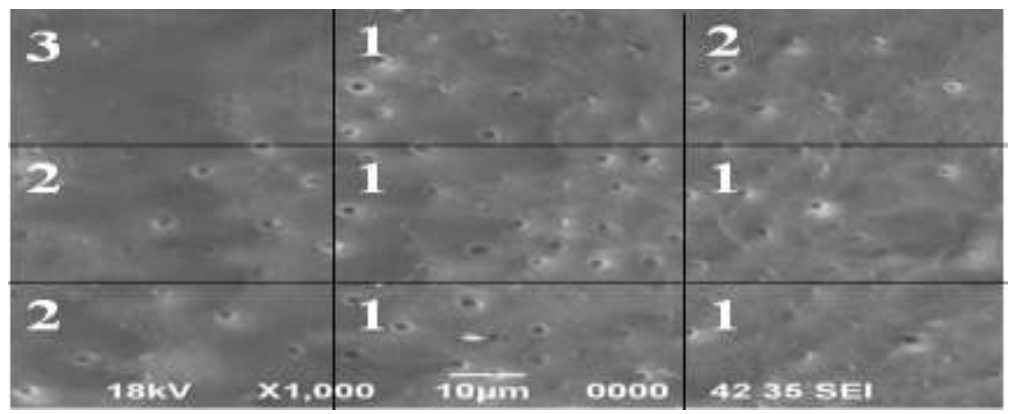

Figure 4. SEM image and scores given by observer of 2,5\% $\mathrm{NaOCl}$ and 75 maleic acid ( X 1000)

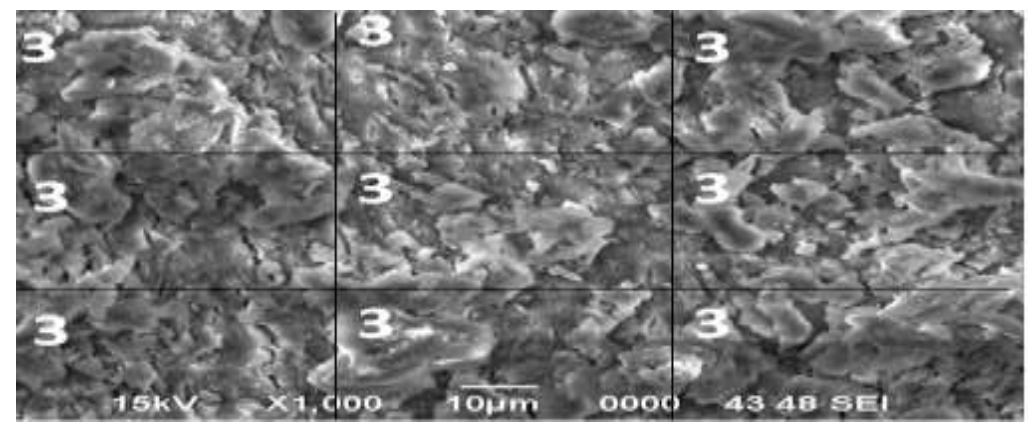

Figure 5. SEM image and scores given by observer of saline soution ( X 1000)

From the test results obtained kappa value $=1$, it meant that there were no difference observation between the two observer. For evaluating the differences between all treatment group can be analyzed by KruskalWallis test. Kruskal-Wallis statistical test resulted value of $p<0.05$ that indicated there were differences of irrigants effect between all treatment groups in removing smear layer of root canals. To evaluate each differences between each treatment group can be analyzed used the Mann-Whitney test (Table 1 )

Table 1. Results of Mann-Whitney test between each group

\begin{tabular}{|c|c|c|c|}
\hline Group & $\mathbf{n}$ & $\begin{array}{l}\text { Total of median } \\
\text { value } \\
\text { group }\end{array}$ & $\mathbf{p}$ \\
\hline $\begin{array}{l}\text { I ( } 25 \% \text { ethanol } \\
\text { extract of lerak } \\
\text { fruit) }\end{array}$ & 10 & 14 & \\
\hline $\begin{array}{l}\text { II (combination of } \\
25 \% \text { ethanol } \\
\text { extract of lerak } \\
\text { fruit and } 2.5 \% \\
\mathrm{NaOCl} \text { ) }\end{array}$ & 10 & 17 & 0.189 \\
\hline $\begin{array}{l}\text { I ( } 25 \% \text { ethanol } \\
\text { extract of lerak } \\
\text { fruit) }\end{array}$ & 10 & 14 & $0.003^{*}$ \\
\hline $\begin{array}{l}\text { III }(2.5 \% \mathrm{NaOCl} \\
\text { and } 17 \% \text { EDTA })\end{array}$ & 10 & 22 & \\
\hline $\begin{array}{l}\text { I }(25 \% \text { ethanol } \\
\text { extract of lerak }\end{array}$ & 10 & 14 & $0.022^{*}$ \\
\hline
\end{tabular}




\begin{tabular}{|c|c|c|c|}
\hline fruit) & & & \\
\hline $\begin{array}{l}\text { IV }(2,5 \% \mathrm{NaOCl} \\
\text { and } 7 \% \text { maleic } \\
\text { acid })\end{array}$ & 10 & 19 & \\
\hline $\begin{array}{l}\text { I ( } 25 \% \text { ethanol } \\
\text { extract of lerak } \\
\text { fruit) }\end{array}$ & 10 & 14 & \multirow[t]{2}{*}{$0.000^{*}$} \\
\hline V (Salin) & 10 & 30 & \\
\hline $\begin{array}{l}\text { II (combination of } \\
25 \% \text { ethanol } \\
\text { extract of lerak } \\
\text { fruit and } 2.5 \% \\
\mathrm{NaOCl} \text { ) }\end{array}$ & 10 & 17 & \multirow[t]{2}{*}{$0.028^{*}$} \\
\hline $\begin{array}{l}\text { III }(2.5 \% \mathrm{NaOCl} \\
\text { and } 17 \% \text { EDTA })\end{array}$ & 10 & 22 & \\
\hline $\begin{array}{l}\text { II (combination of } \\
25 \% \text { ethanol } \\
\text { extract of lerak } \\
\text { fruit and } 2.5 \% \\
\mathrm{NaOCl} \text { ) }\end{array}$ & 10 & 17 & \multirow[t]{2}{*}{0.276} \\
\hline $\begin{array}{l}\text { IV }(2,5 \% \mathrm{NaOCl} \\
\text { and } 7 \% \text { maleic } \\
\text { acid })\end{array}$ & 10 & 19 & \\
\hline
\end{tabular}

\begin{tabular}{|c|c|c|c|}
\hline Group & $\mathbf{n}$ & $\begin{array}{lr}\text { Total of } & \text { median } \\
\text { value } & \text { each } \\
\text { group }\end{array}$ & $\mathbf{p}$ \\
\hline $\begin{array}{l}\text { II (combination of } \\
25 \% \text { ethanol } \\
\text { extract of lerak } \\
\text { fruit and } 2.5 \% \\
\mathrm{NaOCl} \mathrm{NaOCl} \\
2,5 \% \text { ) }\end{array}$ & 10 & 17 & \multirow[t]{2}{*}{$0.000^{*}$} \\
\hline $\mathrm{V}$ (Saline) & 10 & 30 & \\
\hline $\begin{array}{l}\mathrm{III}(2.5 \% \mathrm{NaOCl} \\
\text { and } 17 \% \text { EDTA })\end{array}$ & 10 & 22 & \multirow[t]{2}{*}{0.088} \\
\hline $\begin{array}{l}\text { IV }(2,5 \% \mathrm{NaOCl} \\
\text { and } 7 \% \text { maleic } \\
\text { acid) }\end{array}$ & 10 & 19 & \\
\hline $\begin{array}{l}\mathrm{III}(2.5 \% \mathrm{NaOCl} \\
\text { and } 17 \% \text { EDTA })\end{array}$ & 10 & 22 & \multirow{2}{*}{$0.000^{*}$} \\
\hline $\mathrm{V}$ (Salin) & 10 & 30 & \\
\hline $\begin{array}{l}\text { IV }(\mathrm{NaOCl} 2,5 \% \\
\text { dan asam maleat } \\
7 \%)\end{array}$ & 10 & 19 & \multirow[t]{2}{*}{$0.000^{*}$} \\
\hline V (Saline) & 10 & 30 & \\
\hline
\end{tabular}

Keterangan : *= significance $\mathrm{p}<0.05$

$\mathrm{n}=$ total of sample

Group I (25\% ethanol extract of lerak fruit) and group II (combination of 25\% ethanol extract of lerak fruit and $2.5 \% \mathrm{NaOCl})$ have the same ability to remove smear layer on apical third of root canal $(\mathrm{p}>0.05)$.

In groups I and III, 25\% ethanol extract of the lerak fruit is more effective in removing smear layer on apical third of root canal compared to $2.5 \% \mathrm{NaOCl}$ and EDTA $17 \%(\mathrm{p}<0.05)$.

The ethanol extract of lerak fruit in concentration of $25 \%$ (group I) is also more effective in removing smear layer on the apical third region compared $2.5 \% \mathrm{NaOCl}$ and $7 \%$ maleic acid (group IV) $(\mathrm{p}<0.05$ ).

Groups III and IV $(2.5 \% \mathrm{NaOCl}$ and $17 \%$ EDTA and $2,5 \% \mathrm{NaOCl}$ and $7 \%$ maleic acid) have the same ability in removing the smear layer ( $\mathrm{p}>0.05)$.

Saline as the negative control group is different significantly with other groups $(\mathrm{p}<0.05)$. Saline showed no effect on smear layer root canals. 


\section{Discussion}

The complexity of root canal anatomy, invasion of microorganisms into the dentinal tubules and smear layer formation during instrumentation is the biggest obstacle in cleaning and shaping of root canal system. ${ }^{23}$ The most difficult of cleaning root canals on apical third is associated with anatomical or morphology root canal. Diameter of root canal on this area is smaller than the other parts, therefore it is difficult to remove smear layer on apical third of root canal. ${ }^{13}$ Jain and Bahuguna (2010) stated that the apical third area has the most root canal canals accessories $(84.74 \%)^{24}$, so root canal irrigation is the most important step that will support the success of root canal treatment because of the actions of irrigation to clean the root canal up to the apical third of the root canal and areas that cannot be achieved by mechanical instrumentation. ${ }^{1,23}$

The results showed there is still smear layer in all groups, but in a different score. The presence of smear layer in all groups may be caused by the instrument used for preparation of root canal in this research is to use a rotary instrument and irrigation technique used also still manually, using a syringe and needle which will affect the distribution of irrigant for cleaning the root canal. ${ }^{25}$ Research of Shrivastava et al. (2015) stated that the use of irrigation techniques with EndoVac is more effectively clean the root canal up to $1 \mathrm{~mm}$ of working length that cause distribution of irrigant on apical third of the root canal is better than irrigation techniques manually using needle and syringe. ${ }^{26}$ The results of scanning electron microscope images showed that solution of $25 \%$ ethanol extract of lerak fruit has ability to remove smear layer on third apial of root canal. In Figure 1 showed that ethanol extract of lerak fruit can clean the root canal from the smear layer and it looks a lot more open dentinal tubules. Ability of lerak fruit can dissolve the smear layer has also been shown in research of Nevi Yanti (2007) ${ }^{13}$, which proved $0.008 \%$ saponin of lerak fruit is proven to clean smear layer on canal walls and research of Elvia Rizka (2008) which showed $0.01 \%$ extracts of lerak fruit can prevent microleakage on apical root canal which it means has ability to remove smear layer. ${ }^{15}$

Using irrigant of $2.5 \% \mathrm{NaOCl}$ with $17 \%$ EDTA is generally used as a root canal irrigant to get effect of organic and inorganic smear layer removal. $\mathrm{NaOCl}$ can dissolve organic tissue through saponification reaction, neutralization and chloramination reactions. ${ }^{1}$ Meanwhile, EDTA can dissolve inorganic by removing metal ions such as calcium and bound chemically through two nitrogen atoms in the amino group and four oxygen atoms in the group carboxyl that causing decalcification dentin. ${ }^{1,15}$

Irrigation solution of $25 \%$ ethanol extract of lerak fruit (group I) is more effective in removing smear layer on apical third compared to group III (a combination of $2.5 \% \mathrm{NaOCl}$ and $17 \%$ EDTA) with $\mathrm{p}<0.05$. Silveira et al. (2013) reported that a combination of $2.5 \% \mathrm{NaOCl}$ and $17 \%$ EDTA are not effective in removing smear layer on the apical third of root canal. ${ }^{8}$ This is probably due to irrigant $2.5 \% \mathrm{NaOCl}$ with $17 \%$ EDTA are less able to penetrate to apical third of root canal with anatomical variations and diameter of the root canal this area is smaller than the other parts that greatly affect the ability of this irrigant in removing smear layer. ${ }^{3,13,23}$

The ethanol extract of lerak fruit in a concentration of $25 \%$ is more effective in removing smear layer on apical third of the root canal area due to the saponin which is the active component of ethanol extract of lerak fruit roles as surfactants or detergents that may lower the surface tension. ${ }^{14}$ Syarifah research (2013) stated that the surface tension of ethanol extract of lerak fruit $5-25 \%$ are lower than $2.5 \% \mathrm{NaOCl} .{ }^{16}$ The low surface tension of $25 \%$ ethanol extract of lerak fruit cause the ethanol extract of lerak fruit is better to penetrate up to apical third of root canal and also root canal region that cannot be achieved by instrumentation alone such as to ramifications area and accessories canal. The low surface tension will also improve the contact of irrigant with dentin wall which greatly affect the role of irrigant not only in dissolving the smear layer, but also to effects of antibacterial and ability in dissolving pulp tissue up to the apical third and to the root canal cannot be achieved by instrumentation of root canal. ${ }^{16,28} \mathrm{NaOCl}$ irrigant also can be combined with maleic acid as a substitute for EDTA. Prabhu et al. (2003) stated that 7\% maleic acid effectively remove the smear layer on apical third of root canal. ${ }^{10}$ This may be due to maleic acid has a low surface tension is $0.06345 \mathrm{~N} \mathrm{~m}$ and has the better effect of demineralization. ${ }^{11}$ In this research, the use of $2.5 \% \mathrm{NaOCl}$ and $7 \%$ maleic acid is not more effective than $25 \%$ ethanol extract of lerak fruit in removing smear layer on apical third of the root canal $(\mathrm{p}<0.05)$.

The ethanol extract of lerak fruit in a concentration of $25 \%$ is more effective in removing smear layer on apical third of the root canal compared to $2.5 \% \mathrm{NaOCl}$ with $17 \%$ EDTA and 2,5\% $\mathrm{NaOCl} 2.5 \%$ with $7 \%$ maleic acid. This is possibly caused by $25 \%$ ethanol extract of lerak fruit can remove organic and inorganic smear layer each time the irrigation of the root canal. The chemical structure of saponin on lerak fruit consist of glycoside (polar compound) and pentacyclic triterpenoids (non polar compound) showed that saponin belonged surfactants (surface active substances) which can dissolve polar and non polar compounds. ${ }^{13}$ Group of hydrophilic (polar compounds) and hydrophobic group (non-polar compounds) in lerak fruit enables saponin in dissolving organic smear layer which has polar and non-polar properties. Research of Teo HY (2015) also reported that ethanol extract of lerak fruit in concentration of $6.25 \%$ to $25 \%$ can dissolve pulp tissue, which the pulp tissue is one of the organic component of smear layer. ${ }^{21}$ while the inorganic layer derived from inorganic components dentin largely contains calcium hydroxyapatite and tricalcium phosphate that are a non-polar compounds will be dissolved by hydrophobic group (non-polar compounds) of saponin in lerak fruit. ${ }^{5,6,13}$

Saline as the 
negative control group is different significantly with other groups $(\mathrm{p}<0.05)$. Saline showed no effect on smear layer root canals. The results of SEM images in saline group are visible smear layer on root canal surface and dentinal tubules. It is also consistent with research of Bogra (2003) stated that the use of saline as irrigant cannot open dentinal tubules and whole canal walls covered debris. ${ }^{29}$ That can be concluded that the ethanol extract of the lerak fruit $25 \%$ had ability to remove smear layer on apical third of root canal and more effective than the $2.5 \%$ $\mathrm{NaOCl}$ with $17 \%$ EDTA and $\mathrm{NaOCl} 2.5 \%$ with $7 \%$ maleic acid.

\section{Acknowledgment}

The authors would like to thank Aini Ramadhani and Keyko A. Darya for their contribution in preparing the study and manuscript.

\section{References}

[1]. Agrawal Vineet S, Rajesh M, Sonali K, Mukesh P. A contemporary overview of endodontic irrigants - A review. Journal of Dental application 2014; 1(6): 105-15.

[2]. Young GR, Parashos P, Messer HH. The principle of technique for cleaning root canal. Australian Dental Journal 2007; 52(1 Suppl): 52- 3 .

[3]. Torabinejad M, Walton RE. Endodontics principles and practice. Missouri: Saunders Elsevier, 2009: 258- 68.

[4]. Kocani F, Kamberi B, Dragusha E, Mrasori S, Haliti F. The cleaning efficiency of the root canal after different instrumentation technique and irrigation protocol: A SEM analysis. Journal of Stomatology 2012; 2: 69-76.

[5]. Dechichi P, Moura CCG. Smear layer: a brief review of general concepts. Part I. characteristics, compounds, structure, bacteria and sealing. RFO UPF 2006; 11(2): 96-9.

[6]. Violich DR, Chandler NP. The smear layer in endodontics-a review. International Endodontic Journal 2010; 43 : 2-15.

[7]. Zakarea NA, Mohammad TH, Taqa AA, Chumbley S, Al- juad S, Batto H. A newly prepared solution for the removal of the smear layer. International Journal of Dental Science and Research 2014; 2(1):19-26.

[8]. Silveira LFM, Silveira CF, Martos J, De castro LAS. Evaluation of the different irrigation regiments with sodium hypoclorite and EDTA in removing the smear layer during root canal preparation. Journal of Microscopy and Ultrastructure 2013: 51-6.

[9]. Paul J. Recent trends in irrigation in endodontics. International Journal of Current Microbiology and Applied Sciences 2014; 3(12): 941-52.

[10]. Prabhu SG, Rahim N, Bhat KS, Mathew J. Comparison of removal of endodontic smear layer using NaOCl, EDTA, and different concentrations of maleic acid - A SEM study. Endodontology 2003; 15: 20-5.

[11]. Kuruvilla A, Jaganath BM, Krishnegowda SC, Ramachandra PKM, Johns DA, Abraham A. A comparative evaluation of smear layer removal by using edta, etidronic acid, and maleic acid as root canal irrigants: An in vitro scanning electron microscopic study. J Conserv Dent 2015; 18(3): 247-51.

[12]. Biro Hukum dan Humas. Keputusan Menteri Ristek RI: Kebijakan strategis nasional dan ilmu pengetahuan dan teknologi (Jakstranas Iptek) 2015-2019.

[13]. Nevi Y. Smear layer removal of saponin from lerak's fruit $0,008 \%$ and $\mathrm{NaOCl} 5 \%$ as intracanal irrigant. Proceeding APDC ke-29, Jakarta, 2007.

[14]. Udarno L, Balitri. Lerak (Sapindus rarak) tanaman industri pengganti sabun. Warta Penelitian dan Pengembangan Tanaman Industri 2009; 15(2): 7-8.

[15]. Nevi Y, Elvia RR. Pengaruh larutan ekstrak buah lerak terhadap pembentukan celah mikro di apikal saluran akar. Dentika Dental Journal 2009;14(2): 203-7.

[16]. Syarifah M. Perbedaan tegangan permukaan ekstrak etanol lerak (Sapindus rarak DC) dengan $\mathrm{NaOCl} 2,5 \%$ sebagai bahan irigasi saluran akar. Skripsi. Medan: FKG USU, 2013: 42.

[17]. Nevi Y, Fadhlina I. Efek antibakteri buah lerak terhadap Streptococcus mutans. Dentika Dental Journal 2009; 14(1): 53-8.

[18]. Nevi Y, Sanny. Efek antibakteri berbagai sediaan lerak terhadap Fusobacterium nucleatum sebagai alternatif larutan irigasi intrakanal. Maj Kedokteran Gigi (Dent J) 2009; 24(4): 147-52.

[19]. Vivi L. Efek antibakteri ekstrak etanol lerak (Sapindus rarak DC) sebagai alternatif bahan irigasi saluran akar terhadap Porphyromonas gingivalis (penelitian in vitro). Proceeding RDME ke-6 FKG USU, Medan, 2014.

[20]. Risya DM. Efek antibakteri ekstrak lerak dalam pelarut etanol terhadap Enterococcus faecalis. Proceeding Program Kreativitas Mahasiswa DP3M Ditjen Dikti Depdiknas, 2009: 24-7.

[21]. Teo HY. Pengaruh konsentrasi dan waktu kontak ekstrak etanol lerak (Sapindus rarak DC) sebagai alternatif bahan irigasi saluran akar terhadap kelarutan jaringan pulpa (penelitian in vitro). Skripsi. Medan: FKG USU, 2015: 43.

[22]. Paragliola R et al. Comparison of smear layer removal using four final-rinse protocol. International Dentistry- Australian 2011; 7(1): $50-2$.

[23]. Winter. Root canal irrigants and disinfectans. American Association of endodontics 2011; 2-5.

[24]. Jain A, Bahuguna R. Pulpal morphology of apical third of root of mandibular first premolar: A laboratory study. Priory Lodge Education Ltd.2010

[25]. Guha C, Gurtu A, Mehrotra A. Manual irrigation agitation technique. Journal of dental science and oral rehabilitation 2012: 8-10.

[26]. Shrivastava S, Nikhade P, Chandak M, Tibdewal G. Comparison of the cleaning efficacy of conventional syringe irrigation, Endo Vac and Laser in removing smear layer from the root canal wall using scanning electron microscope: An in vitro study 2015;14(5): 45-50.

[27]. Gu Li-sha, Kim JR, Ling J, Choi KK, David H, Tay FR. Review of contemporary irrigant agitation techniques and devices. JOE 2009; 35(6): 791- 800.

[28]. Giardino L, Ambu E, Becce C, et al. Surface tension comparison of four common root canal irrigant and two new irrigant containing antibiotic. J Endo 2006; 32(11): 1091-2.

[29]. Bogra, Nikhil. Studi of dimercapto siccinic acid, sodium hypochlorite and their combination used as irrigant in root canals. J Endod 2003; 15: 19-25. 